\title{
Species Identification and Confirmation of Human and Animal Cell Lines: A PCR-Based Method
}

BioTechniques 32:432-440 (February 2002)

\author{
B. Parodi, O. Aresu, D. Bini ${ }^{1}$, \\ R. Lorenzini, F. Schena, \\ P. Visconti, M. Cesaro, \\ D. Ferrera, V. Andreotti, \\ and T. Ruzzon \\ National Institute for Cancer \\ Research and 'TIB Molbiol, \\ Genoa, Italy
}

\section{INTRODUCTION}

Continuous cell lines are widely used tools in research laboratories around the world. These cell lines are often exchanged between laboratories without any guarantee of their real origin, their names are often truncated and misspelled, and records are not always kept of the history of the ampoules. Thus, cell cultures can be grown, maintained, and used for years without confirming even the species of origin.

However, the scientific community does not recognize misidentification of cell lines as a major concern. Little effort is spent in laboratories to exclude contamination of cell lines with cells from another individual or species, and subsequent overgrowth has occurred $(20,24)$. In fact, the researchers give more attention to the contamination by microorganisms $(6,7,12,18,20,23)$. Unlike bacterial and fungal contamination, cell cross-contamination is not readily detectable, and the morphology and behavior of the cells in culture can remain unchanged. This is true also for mycoplasma contamination, which is not easily detected, but the awareness of the consequences of this is growing in the scientific community, and a number of papers have been published in the last few years on falsification of data because of mycoplasma contamination $(4,26,30)$. On the contrary, the literature on cell cross-contamination is limited in quantity, and the scientific community is not sufficiently responsive about problems related to this type of contamination.

The risk of cell-culture overgrowth by unrelated cells was first recognized in
$1957(5,20)$. Since then, cross-contamination has been detected by karyology, transplantation, and hemagglutination experiments $(2,34)$, immunofluorescence (31), and DNA fingerprinting (22, 32 ). In 1966 , the isoenzyme polymorphism was implemented as a genetic marker (11), and G6PD polymorphism clarified the problem of HeLa cell contamination $(8,9)$. Biochemical analysis of isoenzyme polymorphism is currently considered to be the standard method in quality control of cell line identification and interspecies contamination and is routinely used by the main Biological Resource Centers around the world (i.e., ATCC, ECACC, DSMZ, and Riken) $(13,14,25,33)$, in conjunction with DNA fingerprinting for intraspecies crosscontamination detection $(5,19,21,32)$.

Very few laboratories perform isoenzyme assay or fingerprinting on a regular basis because of the cost and com plexity of the assays. In addition and most importantly, journal editorial boards, study sections, and others supporting fine research frequently do not insist that certification of cell line species and origin be included. In recent years, PCR has become a widespread tool commonly used in most research laboratories (29). The assays described could easily be added to strengthen quality-control programs in even the most modest cell culture facility.

\section{MATERIALS AND METHODS}

\section{Cell Cultures}

A panel of 35 Interlab Cell Line Col- 
lection (ICLC)-certified continuous cell lines $(27,28)$ was used in this work. Table 1 shows the list of cell lines with the available origin data. Among the cell lines, normal, virus-transformed, and tumoral cell lines are well represented. The age of the donor ranges from em bryo stage to adult, and, within the species, different strains/ethnic origins have been taken into account. The cell lines were grown in $75-\mathrm{cm}^{2}$ plastic culture flasks in their respective culture media (Invitrogen, Milano, Italy and Biochrom KG, Berlin, Germany) in the absence of antibiotics and supplemented with 10\%-20\% heat-inactivated (30 min at $56^{\circ} \mathrm{C}$ ) FCS (Mascia Brunelli S.p.A., Milano, Italy) and when relevant with other supplements, according to the protocols given in the ICLC Catalogue of Human and Animal Cell Lines, available at www.iclc.it. Flasks were incubated in a humidified $5 \% \mathrm{CO}_{2}$ and $95 \%$ air atmosphere. All the cell cultures were mycoplasma free, as assessed by at least two methods: bisbenzimmide (Hoechst 33258) DNA fluorescence staining $(1,3)$ and PCR analysis (16).

\section{Isoenzyme Analysis}

The species of origin of all the cell lines, as certified by the depositor, was verified and confirmed by isoenzyme analysis with the reagents and equipment provided by the AuthentiKit ${ }^{\mathrm{TM}}$ System (Innovative Chemistry, Marshfield, MA, USA) (17). The electrophoretic mobility of at least two different isoenzymes from a panel of seven (AST, G6PD, LD, MD, MPI, NP, and Pep B) was determined for each cell line (Table 1). Briefly, a pellet containing 5-10 $\times$ $10^{6}$ cells was resuspended in an equal volume of Cell Extraction Buffer (Tris Buffer, EDTA, and detergent in deionized water, $\mathrm{pH} 8.0$ ), allowed to stand for approximately $15 \mathrm{~min}$, and then centrifuged for $5 \mathrm{~min}$ at $2000 \times \mathrm{g}$ at $4^{\circ} \mathrm{C}$. The resulting supernatant containing extracted proteins was retained, and 1-3 $\mu \mathrm{L}$ were loaded onto thin agarose gels and subjected to electrophoresis for 25 $\min$ at $160 \mathrm{~V}$. The gel was covered with the enzyme reagent specific for one of the enzymes being analyzed and then incubated at $37^{\circ} \mathrm{C}$ for $5-20 \mathrm{~min}$. The result was the formation of an insoluble band to mark the location of the en- zymes in the gel. The enzyme migration distances were measured and compared with values of standardized migration distances for the different species.

\section{PCR Analysis}

Sample preparation. One milliliter of cell culture suspension with $5 \times 10^{5}$ cells was centrifuged at $12800 \times g$ for 6 min. The resulting pellet was washed with PBS (Invitrogen) and centrifuged at $12800 \times g$ for $6 \mathrm{~min}$. The pellet was then resuspended in $100 \mu \mathrm{L}$ extraction buffer consisting of $10 \mu \mathrm{L} 10 \times$ PCR Buffer (100 mM Tris-HCl, pH 8.3, 500 $\mathrm{mM} \mathrm{KCl}, 0.01 \%$ gelatin) (GeneCraft, Münster, Germany), $2.5 \mathrm{mM} \mathrm{MgCl}_{2}$ (GeneCraft), $4.5 \mu \mathrm{L} 10 \%$ Nonidet $^{\mathrm{TM}} \mathrm{P}$ 40 in sterile distilled water (Roche Molecular Biochemicals, Mannheim, Germany), $4.5 \mu \mathrm{L} 10 \%$ Tween ${ }^{\circledR} 20$ in sterile distilled water (Sigma-Aldrich S.r.1., Milano, Italy), $0.6 \mu \mathrm{L}$ proteinase $\mathrm{K}$ (Invitrogen) from a $10 \mathrm{mg} / \mathrm{mL}$ solution in sterile distilled water, and 70.4 $\mu \mathrm{L}$ sterile distilled water. The sample was incubated for $1 \mathrm{~h}$ at $60^{\circ} \mathrm{C}$, followed by $10 \mathrm{~min}$ at $95^{\circ} \mathrm{C}$. Samples were stored frozen at $-20^{\circ} \mathrm{C}$.

Negative control. For each experiment, a "negative cell pool" containing $5 \times 10^{4}$ cells from each of eight cell lines representing eight different species, with the exclusion of the species under investigation, was used as negative control of PCR. As an example, the "no dog" pool will contain cells of human, mouse, rat, monkey, cat, rabbit, horse, and hamster origin. The follow ing cell lines are used: Caski, Mab 62B1PC, B104, V-79, Vero, Cf2Th, PG-4 (S+L-), SIRC, and E.Derm (Table 1). In some experiments, additional control lanes with $5 \times 10^{5}$ cells from single selected species were added.

Positive control. In each experiment, a "positive cell pool" was used as positive control of PCR, containing $5 \times$ $10^{4}$ cells of each of the following nine cell lines from the nine different species for which the primer pairs had been prepared: Caski, AKR/14C, JTC27, V-79, Vero, Cf2Th, PG-4 (S+L-), SIRC, and E.Derm.

Primers. Oligonucleotide primer pairs, GenBank ${ }^{\circledR}$ information, and amplification product sizes are listed in Table 2. Oligonucleotides were supplied by TIB Molbiol S.r.l. (Genova, Italy). Cytochrome c oxidase subunit I (cox I) sequence for Homo sapiens, Rattus norvegicus, Canis familiaris, Oryctolagus cuniculus, Mus musculus, Felis catus, Equus caballus, Cercopithecus aethiops and cytochrome b sequence for Cricetulus griseus were employed to select highly specific amplification primers. We used software for multiple sequence alignment analysis to evaluate the polymorphic positions (10).

Amplification. For amplification, the reaction mixture $(100 \mu \mathrm{L})$ contained $79 \mu \mathrm{L}$ PCR mixture $[5 \mu \mathrm{L}$ each primer (forward and reverse) (10 $\mathrm{pmol} / \mu \mathrm{L}), 10 \mu \mathrm{L} 10 \times$ PCR buffer $(100$ $\mathrm{mM}$ Tris- $\mathrm{HCl}, \mathrm{pH} 8.3,500 \mathrm{mM} \mathrm{KCl}$ ), $0.01 \%$ gelatin, $15 \mathrm{mM} \mathrm{MgCl}_{2}$ ), 200 $\mu \mathrm{M}$ dNTP (Hybaid, Teddington, UK), $10 \mu$ L DMSO (Sigma-Aldrich S.r.l), 39 $\mu \mathrm{L}$ sterile distilled water], $20 \mu \mathrm{L}$ sample, and 2.5 U Taq DNA polymerase (GeneCraft). Reaction mixtures were covered with $50 \mu \mathrm{L}$ light mineral oil (Sigma-Aldrich S.r.1.) and heated to $95^{\circ} \mathrm{C}$ for $5 \mathrm{~min}$, followed by 30 cycles of denaturation at $95^{\circ} \mathrm{C}$ for $30 \mathrm{~s}$, primer annealing at $55^{\circ} \mathrm{C}$ for $30 \mathrm{~s}$, and extension at $72^{\circ} \mathrm{C}$ for $1 \mathrm{~min}$. In the last cycle, the extension step was prolonged to 5 min. Amplification was carried out in an $\mathrm{OMN}-\mathrm{E}^{\mathrm{TM}}$ programmable thermal cycler (Hybaid). At least one negative control was incorporated into each experiment. The amplification product $(10 \mu \mathrm{L})$ was run on $2 \%$ agarose gel (Bio-Rad Laboratories S.r.l., Milano, Italy), stained with ethidium bromide (Invitrogen), visualized under UV light, and photographed.

\section{Sensitivity of the PCR Detection}

To determine the sensitivity of the PCR amplification, DNA extracts from cultures of $1 \times 10^{5}$ cell lines were diluted $1 / 5,1 / 12.5,1 / 25,1 / 125$, and $1 / 625$ with sterile distilled water, down to an amount of DNA corresponding to 160 cells, and tested with the respective species-specific primer pairs. The following cell lines were used: MPP89, L929, GS-9L, V-79, Vero, Cf2Th, PG4 (S+L-), SIRC, and E.Derm.

To verify the ability of the assay to detect interspecies cross-contamination, cells from a rat cell culture (RBL1) were mixed with different propor- 
Table 1. List of the Cell Lines Tested

\begin{tabular}{|c|c|c|c|c|c|c|}
\hline $\begin{array}{l}\text { Cell Line } \\
\text { Name }\end{array}$ & Species & $\begin{array}{c}\text { Identified by } \\
\text { Isoenzyme Analysis }\end{array}$ & $\begin{array}{l}\text { Strain/Ethnic } \\
\text { Group }\end{array}$ & Sex & Age & CellType \\
\hline CaSki & human & AST, MPI & Caucasian & female & 40 years & $\begin{array}{l}\text { cervix carcinoma, } \\
\text { epidermoid }\end{array}$ \\
\hline HCT-15 & human & AST, MPI & & & & colon adenocarcinoma \\
\hline HeLa S3 & human & $\begin{array}{l}\text { AST, G6PD, MD, NP, } \\
\text { Pep B }\end{array}$ & Black & female & 31 years & $\begin{array}{l}\text { cervix carcinoma, } \\
\text { epitheloid }\end{array}$ \\
\hline IM-9 & human & AST, MPI & & female & & B-lymphoblast \\
\hline MCF7-432 & human & G6PD, NP & Caucasian & female & 69 years & breast adenocarcinoma \\
\hline $\mathrm{ME}-180$ & human & AST, G6PD, Pep B & Caucasian & female & 66 years & $\begin{array}{l}\text { cervix carcinoma, } \\
\text { epidermoid }\end{array}$ \\
\hline MPP89 & human & AST, MPI & Caucasian & male & 67 years & mesothelioma \\
\hline SW1353 & human & AST, MPI & Caucasian & female & 72 years & bone chondrosarcoma \\
\hline THP-1 & human & G6PD, NP & & male & 1 year & $\begin{array}{l}\text { leukemia, acute } \\
\text { monocytic }\end{array}$ \\
\hline U-937 & human & AST, NP, Pep B & Caucasian & male & 37 years & $\begin{array}{l}\text { pleural effusion, } \\
\text { lymphoma, histiocytic }\end{array}$ \\
\hline 3Т3 & mouse & G6PD, MD, NP & Swiss albino & & embryo & fibroblasts \\
\hline $\mathrm{AKR} / 14 \mathrm{C}$ & mouse & $\mathrm{MD}, \mathrm{NP}$ & $A K R / J$ & & & thymocytes \\
\hline B16-F10 & mouse & NP, Pep B & C57BL/6 & & & melanoma \\
\hline Hepa 1-clc7 & mouse & MD, Pep B & C57L/J & & & hepatoma \\
\hline L929 & mouse & $\begin{array}{l}\text { AST, G6PD, MD, NP, } \\
\text { Pep B }\end{array}$ & $\mathrm{C} 3 \mathrm{H} / \mathrm{An}$ & male & 100 days & connective tissue \\
\hline Mab 62B1PC & mouse & MD, MPI & $\mathrm{BALB} / \mathrm{c}$ & & & hybridoma \\
\hline Mab 8A-PC & mouse & MD, MPI & $\mathrm{BALB} / \mathrm{c}$ & & & hybridoma \\
\hline P19 & mouse & MD, Pep B & $\mathrm{C} 3 \mathrm{H} . \mathrm{He}$ & & embryo & teratocarcinoma \\
\hline B104 & rat & $\mathrm{MD}, \mathrm{NP}$ & BDIX & & adult & brain neuroblastoma \\
\hline C6 & rat & AST, MD, NP & & & & glial tumor \\
\hline FAO & rat & $\mathrm{MD}, \mathrm{NP}$ & & & & hepatoma \\
\hline GS-9L & rat & AST, MD & & & & glioma \\
\hline JTC-27 & rat & $\mathrm{MD}, \mathrm{NP}$ & & & & liver hepatoma \\
\hline RBL-1 & rat & $\mathrm{MD}, \mathrm{NP}$ & Wistar & & & leukemia, basophilic \\
\hline $\mathrm{CHO}$ & $\begin{array}{l}\text { Chinese } \\
\text { hamster }\end{array}$ & AST, MD & & female & & ovary \\
\hline CHO-SSR1 & $\begin{array}{l}\text { Chinese } \\
\text { hamster }\end{array}$ & $\mathrm{MD}, \mathrm{NP}$ & & female & adult & ovary, transfected \\
\hline V-79 & $\begin{array}{l}\text { Chinese } \\
\text { hamster }\end{array}$ & $\mathrm{MD}, \mathrm{NP}$ & & male & & lung fibroblasts \\
\hline cos-7 & $\begin{array}{l}\text { African Green } \\
\text { monkey }\end{array}$ & $\mathrm{MD}, \mathrm{NP}$ & & & & $\begin{array}{l}\text { kidney, SV40 } \\
\text { transformed }\end{array}$ \\
\hline Vero & $\begin{array}{l}\text { African Green } \\
\text { monkey }\end{array}$ & AST, MD, NP, Pep B & & & adult & kidney \\
\hline Cf2Th & dog & G6PD, MD & & & & thymus \\
\hline DH82 & dog & AST, G6PD, Pep B & $\begin{array}{l}\text { Golden } \\
\text { retriever }\end{array}$ & male & 10 years & monocyte-macrophage \\
\hline PG-4 (S+L-) & cat & G6PD, MD & & & fetal & $\begin{array}{l}\text { brain, M-MSV } \\
\text { transformed }\end{array}$ \\
\hline S+L-CAT2 & cat & AST, G6PD, LD & & & & $\begin{array}{l}\text { kidney, MSV } \\
\text { transformed }\end{array}$ \\
\hline SIRC & rabbit & AST, G6PD, Pep B & & & & cornea \\
\hline E. Derm & horse & NP & & female & 4 years & dermis \\
\hline
\end{tabular}


Table 2. Species-Specific Primers

\begin{tabular}{|c|c|c|c|c|c|}
\hline Species & $\begin{array}{l}\text { Gene GenBank } \\
\text { Accession No. }\end{array}$ & Position & Direction & Sequence & $\begin{array}{l}\text { ize of Amplified } \\
\text { Product (bp) }\end{array}$ \\
\hline Human & $\begin{array}{l}\operatorname{cox} I \\
\text { J01415 }\end{array}$ & $\begin{array}{l}5967-5988 \\
6173-6194\end{array}$ & $\begin{array}{l}\text { for: } 5^{\prime} \\
\text { rev: } 5^{\prime}\end{array}$ & $\begin{array}{l}\text { TTCGGCGCATGAGCTGGAGTCC } \\
\text { TATGCGGGGAAACGCCATATCG }\end{array}$ & 228 \\
\hline Mouse & $\begin{array}{l}\operatorname{cox} I \\
\text { J01420 }\end{array}$ & $\begin{array}{l}5895-5916 \\
6023-6044\end{array}$ & $\begin{array}{l}\text { for: } 5^{\prime} \\
\text { rev: } 5^{\prime}\end{array}$ & $\begin{array}{l}\text { ATTACAGCCGTACTGCTCCTAT } \\
\text { CCCAAAGAATCAGAACAGATGC }\end{array}$ & 150 \\
\hline Rat & $\begin{array}{l}\text { cox I } \\
\text { NC001665 }\end{array}$ & $\begin{array}{l}6022-6043 \\
6196-6217\end{array}$ & $\begin{array}{l}\text { for: } 5^{\prime} \\
\text { rev: } 5^{\prime}\end{array}$ & $\begin{array}{l}\text { CGGCCACCCAGAAGTGTACATC } \\
\text { GGCTCGGGTGTCTACATCTAGG }\end{array}$ & 196 \\
\hline Chinese hamster & $\begin{array}{l}\text { Cytochrome b } \\
\text { AB033693 }\end{array}$ & $\begin{array}{l}196-216 \\
468-488\end{array}$ & $\begin{array}{l}\text { for: } 5^{\prime} \\
\text { rev: } 5^{\prime}\end{array}$ & $\begin{array}{l}\text { GTGACCCATATCTGCCGAGAT } \\
\text { CATTCTACTAGGGTGGTGCCC }\end{array}$ & 293 \\
\hline $\begin{array}{l}\text { African Green } \\
\text { monkey }\end{array}$ & $\begin{array}{l}\text { cox I } \\
\text { AF312703 }\end{array}$ & $\begin{array}{l}320-339 \\
522-541\end{array}$ & $\begin{array}{l}\text { for: } 5^{\prime} \\
\text { rev: } 5^{\prime}\end{array}$ & $\begin{array}{l}\text { ССTCTTTCCTGCTGCTAATG } \\
\text { TTTGATACTGGGATATGGCG }\end{array}$ & 222 \\
\hline Dog & $\begin{array}{l}\text { cox I } \\
\text { U96639 }\end{array}$ & $\begin{array}{l}5466-5487 \\
5597-5618\end{array}$ & $\begin{array}{l}\text { for: } 5^{\prime} \\
\text { rev: } 5^{\prime}\end{array}$ & $\begin{array}{l}\text { GAACTAGGTCAGCCCGGTACTT } \\
\text { CGGAGCACCAATTATTAACGGC }\end{array}$ & 153 \\
\hline Cat & $\begin{array}{l}\text { cox I } \\
\text { NC001700 }\end{array}$ & $\begin{array}{l}7413-7434 \\
7571-7592\end{array}$ & $\begin{array}{l}\text { for: } 5^{\prime} \\
\text { rev: } 5^{\prime}\end{array}$ & $\begin{array}{l}\text { TTCTCAGGATATACCCTTGACA } \\
\text { GAAAGAGCCCATTGAGGAAATC }\end{array}$ & 180 \\
\hline Rabbit & $\begin{array}{l}\text { Coxl } \\
\text { NC001913 }\end{array}$ & $\begin{array}{l}5587-5608 \\
5716-5737\end{array}$ & $\begin{array}{l}\text { for: } 5^{\prime} \\
\text { rev: } 5^{\prime}\end{array}$ & $\begin{array}{l}\text { CGGGAACTGGCTTGTCCCCCTG } \\
\text { AACAGTTCAGCCAGTCCCCGCC }\end{array}$ & 151 \\
\hline Horse & $\begin{array}{l}\operatorname{cox} I \\
\text { NC001640 }\end{array}$ & $\begin{array}{l}5456-5475 \\
5671-5690\end{array}$ & $\begin{array}{l}\text { for: } 5^{\prime} \\
\text { rev: } 5^{\prime}\end{array}$ & $\begin{array}{l}\text { CCCTAAGCCTCCTAATCCGT } \\
\text { AGGAATGATGGGGGAAGTAA }\end{array}$ & 235 \\
\hline
\end{tabular}

tions $(0 \%, 1 \%, 2 \%, 5 \%, 10 \%, 25 \%$, $50 \%$, and $100 \%$ ) of cells from an African Green monkey cell line (VERO): DNA extracts of $1 \times 10^{5}$ cells from each mixture were then tested with the monkey-specific primer pairs.

\section{RESULTS}

PCR Amplification with SpeciesSpecific Primer Pairs

Human cell lines. Ten human cell lines were used for testing the specificity of primers designed to recognize a region of human cox I gene (Tables 1 and 2). Specific amplification was detected in all human cell lines and in the positive control, while no amplification was detected in the negative controls. Figure 1B shows a representative result.

Mouse cell lines. DNA from eight murine cell lines was analyzed by PCR using primers specific for the mouse cox I gene region. The murine origin was confirmed for all eight cell lines tested (Figure 1C shows a representative re- sult), while no amplification was detected in negative controls. The primer specificity was confirmed by PCR amplification of DNA from the positive cell pool and the "no mouse negative cell pool" of cell lines (Figure 1A).

Rat cell lines. Six cell lines were tested with specific DNA PCR amplification of a fragment from the rat cox I gene region. The rat origin was confirmed for all the six cell lines (Figure 1D shows results relative to four cell lines). Amplification was detected also in the positive cell pool (Figure 1A), while no amplification was detected in the negative controls (Figure 1, A and D).

Chinese hamster cell lines. Three hamster cell lines were used for testing the specificity of primers specific for the Chinese hamster cytochrome $b$ gene. Specific amplification was detected in all the hamster cell lines and in the cell pool used as positive control. No amplification was detected in the negative controls (Figure 1E).

African Green monkey cell lines. Two monkey cell lines were used for testing the specificity of primers de- signed to recognize a fragment of the African Green monkey cox I gene. Specific amplification was detected in both the cell lines and in the cell pool used as positive control. No amplification was detected in the negative controls (Figure 1F).

Dog cell lines. DNA from two cell lines was analyzed by PCR with a pair of primers specific for the dog cox I region. Specific amplification was detected in both cell lines and in the positive control. No amplification was seen in the cell pool used as negative control (Figure 1, A and G).

Cat cell lines. DNA from two cell lines was analyzed by PCR with a pair of primers that amplify a fragment from the cat cox I region. Specific amplification was detected in both cell lines and in the positive control, while no amplification was detected in the negative control (Figure 1, A and G).

Rabbit cell lines. DNA from SIRC cell line was analyzed by PCR with a pair of primers specific for the rabbit cox I region. Specific amplification was detected in the cell line and in the cell 
pool used as positive control. No amplification was detected in the cell pool used as negative control (Figure 1H).

Horse cell lines. DNA from the E.Derm cell line, previously tested with four isoenzymes (LD, MD, NP, and Pep B) but confirmed only with NP, was analyzed by PCR with a pair of primers that amplify a fragment from the horse cox I region. Specific amplification was detected in the cell line and in the positive control, while no amplification was detected in the negative controls (Figure $1, \mathrm{~A}$ and I).

\section{Sensitivity of the PCR Detection}

The detection limits for species identification were determined by PCR amplification, as described in Materials and Methods. The lower limit of detection was determined to be about $4 \times 10^{3}$ cells for Chinese hamster, 160 cells for African Green monkey, and 800 cells for the other species tested (Figure 2).

The ability of the assay to detect interspecies cross-contamination was verified by an experiment where rat cells were mixed with different proportions of monkey cells and tested by PCR with the monkey-specific primer pairs. The specific band is evident in all lanes where the monkey cell line is present, down to the lower concentration tested $(1 \%)$, and no band is detected in the negative control (100\% rat) (data not shown).

\section{DISCUSSION}

A PCR-based method for defining or confirming the species of origin for human and animal cell lines and for detecting interspecies cross-contamination and misidentification is presented in this paper. Specific primer pairs have been designed for either cox I gene or cytochrome $b$ gene of nine different species (human, cat, dog, mouse, rat, horse, rabbit, African Green monkey, and Chinese hamster) among the most widely used in research laboratories (Table 2).

A panel of 35 cell lines was tested (Table 1) whose species of origin had been previously confirmed by isoenzyme biochemical analysis. In all the experiments, the cell lines, when tested with the relevant primer pair, showed a band of amplification corresponding to the expected size of the fragment am plified, while no amplification was seen when primer pairs specific for different species were used.

The sensitivity of the assay was determined for all the species tested by dilution assays (Figure 2): a distinct band is detectable at a dilution ranging between $4 \times 10^{3}$ (hamster) and $1.6 \times 10^{2}$ cells (monkey). In a cross-contamination assay, a band of amplification was detected in the presence of down to $1 \%$ of contaminating cells (data not shown). On the basis of these results, positive and negative cell pools have been prepared as positive and negative controls.

When the method described in this paper is compared to the isoenzyme biochemical analysis, some considerations can be done. The isoenzyme analysis is considered the most reliable test for identification of species of cell lines and is widely used by the cell line repositories around the world. The

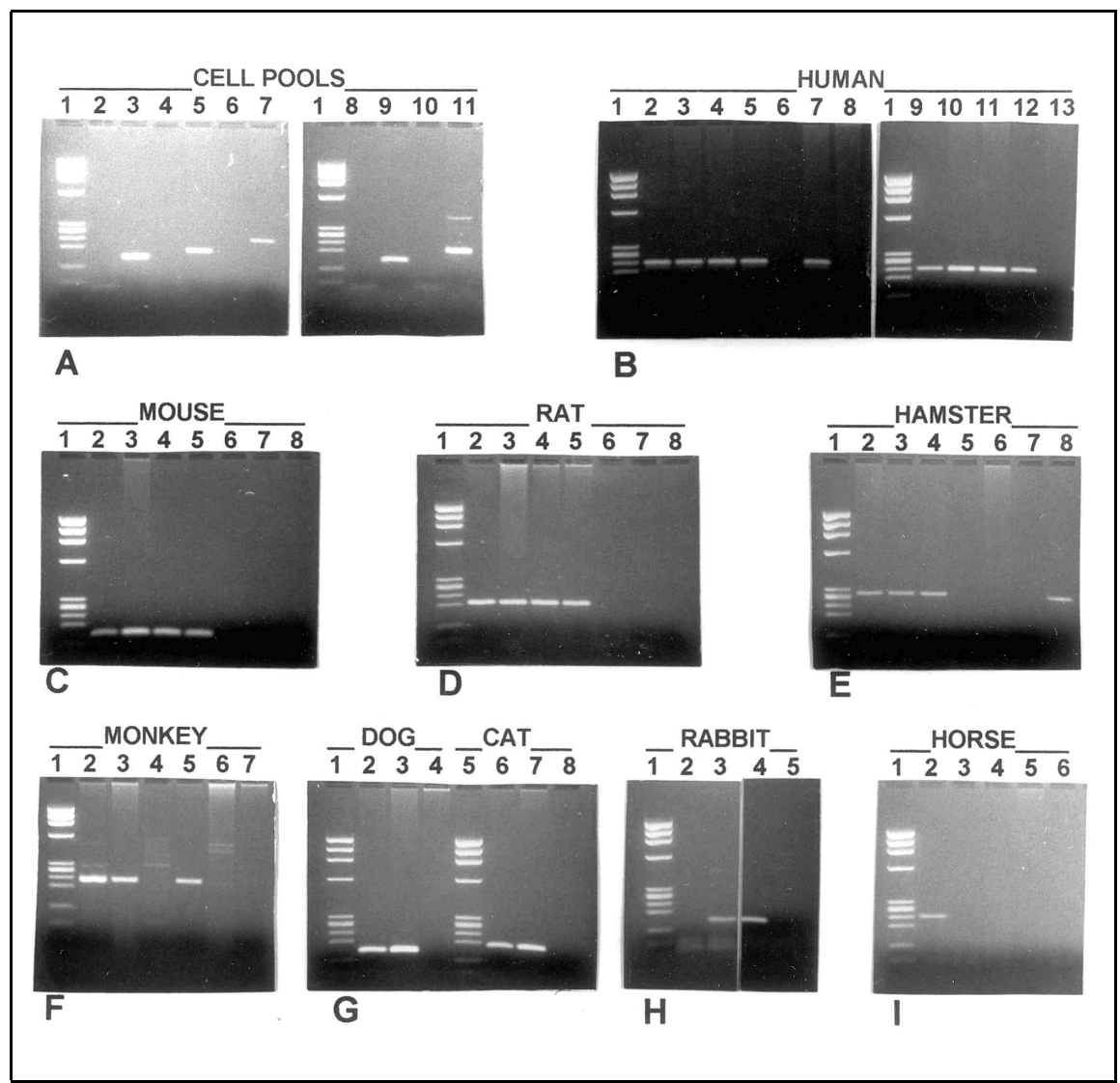

Figure 1. PCR amplification with species-specific primers pairs. Amplified fragments (see Table 2 for size and respective gene region) were detected by ethidium bromide staining after agarose gel electrophoresis. Lane 1, molecular weight marker (phi X 174/HaeIII DNA, $1 \mu \mathrm{g}$; Invitrogen). (A) PCR am plification of DNA extracted from negative and positive cell pools. Lanes $2,4,6,8$, and 10 , negative cell pools (dog, cat, horse, mouse, and rat, respectively); lanes $3,5,7,9,11$, positive cell pools (dog, cat, horse, mouse, and rat). (B) Human-specific PCR. Lanes 2-5 and lanes 9-12, HeLa S3, MCF7-432, ME180, THP-1, U-937, CaSki, SW1353, and IM-9; lanes 6 and 13, negative cell pool; lane 7, positive cell pool; lane 8, African Green monkey COS-7. (C) Mouse-specific PCR. Lanes 2-5, AKR/14C, Mab 8APC, L929, and 3T3; lane 6, rat C6; lane 7, human HCT-15; lane 8, negative cell pool. (D) Rat-specific PCR. Lanes 2-5, B104, JTC-27, FAO, and C6; lane 6, mouse 3T3; lane 7, human U-937; lane 8, negative cell pool. (E) Chinese hamster-specific PCR. Lanes 2-4, V-79, CHO, and CHO-SSR1; lane 5, mouse Mab 8A-PC; lane 6, human U-937; lane 7, negative cell pool; lane 8, positive cell pool. (F) African Green monkey-specific PCR. Lanes 2 and 3, Vero and COS-7; lane 4, negative cell pool; lane 5, positive cell pool; lane 6, human HeLa S3; lane 7, mouse L929. (G) Dog- and cat-specific PCR. Lane 2, DH82; lane 3, Cf2Th; lane 4, dog negative cell pool; lane 6, S+L-CAT2; lane 7, PG-4 (S+L-); lane 8, cat negative cell pool. (H) Rabbit-specific PCR. Lane 2, negative cell pool; lane 3, positive cell pool; lane 4, SIRC; lane 5, distilled water. (I) Horse-specific PCR. Lane 2, E.Derm; lane 3, mouse Mab 8A-PC; lane 4, rat JTC-27; lane 5, human U-937; lane 6, negative cell pool. 
analysis of a cell line with 3-5 isoenzyme substrates can identify or confirm the species of origin of the cell line and can detect and identify interspecies cross-contamination, provided the percentage of the contaminating cells is over $25 \%$ (15) or $11 \%$ (25). On the other hand, it requires specific equipment and expensive reagents, and very few research laboratories regularly perform the test on their cell lines for a routine checking. Furthermore, the isoenzyme assay does not always allow one to confirm the species of a cell line. For exam ple, for the equine E.derm cell line, only one enzyme (NP) gave a result compatible with the expected origin (Table 2).

The PCR has become a routine technique in a large majority of the biomedical research laboratories, and the ap- plication of this technique to the authentication of the cell lines implies neither dedicated equipment nor expensive reagents.

The present assay allows one to confirm the species of origin of a cell line by a single PCR amplification, and a cross contamination by a defined species can be detected by a single assay with a sensitivity ranging between $1 \%$ and $4 \%$ of contaminating cells. Furthermore, the equine origin of the cell line E.derm could be easily confirmed by this assay.

Analysis of the catalogs of the main culture collections worldwide shows that the cell lines of human, mouse, and rat origin cover $77 \%-92 \%$ of the material available. It can be postulated that these are also the species mostly used

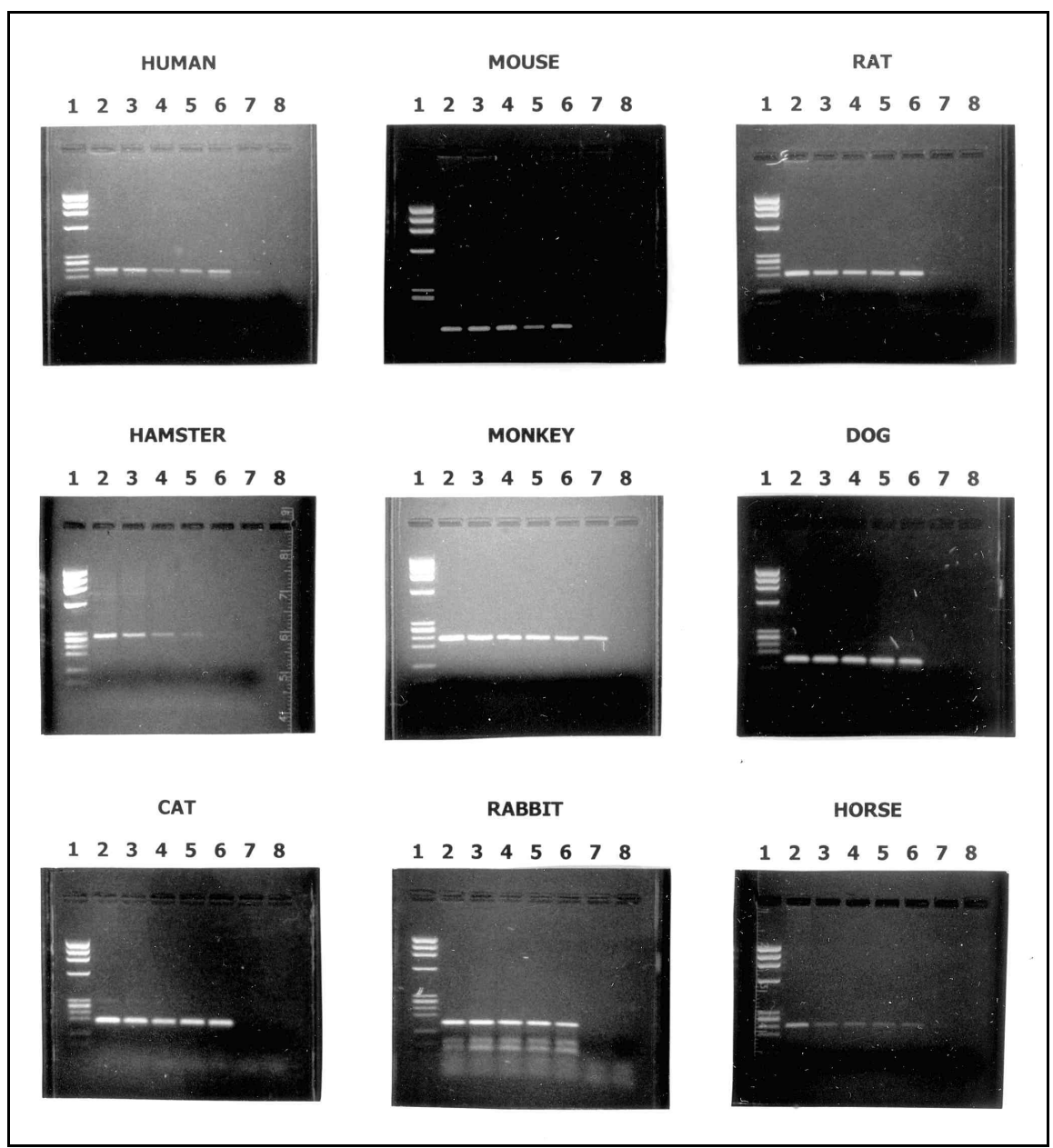

Figure 2. Sensitivity of the PCR amplification. Amplified fragments (see Table 2 for size and respective gene region) were detected by ethidium bromide staining after agarose gel electrophoresis. Lane 1, phi X 174/Hae III DNA size standard; lanes 2-7, serial dilutions of cell DNA in distilled water; lane 2, DNA extracted from $1 \times 10^{5}$ cells (non-diluted); lane 3 , extract diluted $1 / 5$; lane $4,1 / 12.5$; lane $5,1 / 25$; lane $6,1 / 125$; lane $7,1 / 625$; lane 8 , distilled water. 
in research laboratories. When interspecies cross-contamination is suspected, the cell line can be checked with the relevant primer pairs, depending on the species of cell lines mostly used in the laboratory. Thus, a simple assay with 3-4 primer pairs, designed to serve as a routine check of the origin of the cell lines, could help in rapidly answering the question whether the cell culture has been overgrown by a cell line of different species or a mislabeling has happened. The use of this test in conjunction with assays able to detect intraspecies contamination (DNA profiling systems, such as multiplex STR profiling) (21) will give an acceptable confidence on the quality of the cell lines used in most laboratories.

\section{ACKNOWLEDGMENTS}

The authors wish to thank Mrs. Nadia Ricchetti for her secretarial help. The work has been funded by the Italian Ministry of University (MURST) in the frame of a project on new assays for cell line authentication.

\section{REFERENCES}

1.Barile, M.F. 1979. Mycoplasma-tissue cell interactions, p. 425-574. In J.G. Tully and R.F. Whitcomb (Eds.), The Mycoplasmas, vol. II. Academic Press, New York.

2.Brand, K.G. and T.J. Syverton. 1960. Im munology of cultivated mammalian cells. Species specificity determined by hemagglutination. J. Natl. Cancer Inst. 24:1007-1009.

3.Chen, T.R. 1977. In situ detection of mycoplasma contamination in cell cultures by fluorescent Hoechst 33258 stain. Exp. Cell Res. 104:255-262.

4.Denecke, J., K. Becker, H. Jürgens, R. Gross, and J.E.A. Wolff. 1999. Falsification of tetrazolium dye (MTT) based cytotoxicity assay results due to mycoplasma contamination of cell cultures. Anticancer Res. 19:12451248.

5.Drexler, H.G., W.G. Dirks, and R.A.F. MacLeod. 1999. False human hematopoietic cell lines: cross-contaminations and misinterpretations. Leukemia 13:1601-1607.

6.Fogh, J. 1973. Contamination in Tissue Culture. Academy Press, New York.

7.Freshney, R.I. 1994. Culture of Animal Cells, p. 243-252. John Wiley \& Sons, New York.

8.Gartler, S.M. 1967. Genetic markers as tracers in cell culture. Natl. Cancer Inst. Monogr. 26:167-195.

9.Gartler, S.M. 1968. Apparent HeLa cell contamination of human heteroploid cell lines. Nature 217:750-751.
10.Hall, T.A. 1999. Symposium on RNA Biology. III. RNA, Tool and Target. Research Triangle Park, North Carolina, USA. October 15-17. Proc. Nucleic Acids Symp. Ser. 41:9598

11.Harris, H. 1996. Enzyme polymorphism in man. Proc. R. Soc. Lond. B Biol. Sci. 164:298-301.

12.Hay, R.J. 1991. Operator-induced contamination in cell culture systems. Dev. Biol. Stand. 75:193-204.

13.Hay, R.J. 1992. Cell line preservation and characterization, p. 95-148. In R.I. Freshney (Ed.), Animal Cell Culture. A Practical Approach, 2nd ed. Oxford University Press, Oxford.

14.Hay, R.S., J. Caputo, and M.L. Macy (Eds). 1992. ATCC Quality Control Methods for Cell Lines, 2nd ed. American Type Culture Collection Publishing, Rockville, MD.

15.Hay, R.J., T.R. Chen, M.L. Macy, and Y.A. Reid. 1992. Replay to "Cell, lines and DNA fingerprinting". In Vitro Cell Dev. Biol. 28A:593-594.

16.Hopert, A., C.C. Uphoff, M. Wirth, H. Hauser, and H.G. Drexler. 1993. Specificity and sensitivity of polymerase chain reaction (PCR) in comparison with other methods for the detection of mycoplasma contamination in cell lines. J. Immunol. Methods 164:91-100.

17.Innovative Chemistry. 1988. AuthentiKit ${ }^{\mathrm{TM}}$ System. Handbook for Cell Authentication and Identification, p. 31-46. 2nd ed. Marshfield, MA.

18.Lincoln, C.K. and M.G. Gabridge. 1998. Cell culture contamination: sources, consequences, prevention, and elimination. Methods Cell Biol. 57:49-65.

19.MacLeod, R.A.F., W.G. Dirks, Y. Matsuo, M. Kaufmann, H. Milch, and H.G. Drexler. 1999. Widespread intraspecies cross-contamination of human tumor cell lines arising at source. Int. J. Cancer 83:555-563.

20.Markovic, O. and N. Markovic. 1998. Cell cross-contamination in cell cultures: the silent and neglected danger. In Vitro Cell Dev. Biol. Anim. 34:1-8.

21.Masters, J.R., J.A. Thomson, B. DalyBurns, Y.A. Reid, W.G. Dirks, P. Packer, L.H. Toji, T. Ohno et al. 2001. Short tandem repeat profiling provides an international reference standard for human cell lines. Proc. Natl. Acad. Sci. USA 98:8012-8017.

22.Masters, J.R., P. Bedford, A. Kearney, S. Povery, and L.M. Franks. 1988. Bladder carcinoma cell line cross-contamination: identification using a locus-specific minisatellite probe. Br. J. Cancer 57:284-286.

23.McGarrity, G.J. 1982. Detection of mycoplasma infection in cell cultures. Adv. Cell Cult. 2:99-131.

24.Nelson-Rees, W.A., D.W. Daniels, and R.R. Flandermeyer. 1981. Cross-contamination of cells in culture. Science 212:446-452.

25.Nims, R.W., A.P. Shoemaker, M.A. Bauernschub, L.J. Rec, and J.W. Harbell. 1998. Sensitivity of isoenzyme analysis for the detection of interspecies cell line cross-contamination. In Vitro Cell Dev. Biol. Anim. 34:3539.

26.Ong, G.L. and M.J. Mattes. 1998. The processing of antibodies bound to B-cell lym phomas: the effect of inadvertent mycoplasma contamination. In Vitro Cell Dev. Biol. Anim. 34:527-528.

27.Parodi, B., O. Aresu, P. Visconti, M. Cesaro, R. Lorenzini, and T. Ruzzon. 2000. The Interlab Cell Line Collection (ICLC). Cell Banks: a service to animal cell technology, p. 313-314. In G. Stacey and A. Doyle (Eds.), Encyclopedia of Cell Technology. Editor-in-Chief R.E. Spier, John Wiley and Sons, New York

28.Parodi, B., O. Aresu, P. Visconti, E. Maggi, A.M. Parodi, and T. Ruzzon. 2000. Authentication and quality control of cell lines at the Interlab Cell Line Collection, p. 282-286. In H. Schoffl, H. Spielmann, and H.A. Tritthart (Eds.), Ersatz und Ergänzungsmethoden zu Tierversuchen. Springer Wien, New York.

29.Saiki, R.K., D.H. Gelfand, S. Stoffel, S.J. Scharf, R. Higuchi, G.T. Horn, K.B. Mullis, and H.A. Erlich. 1988. Primer-directed enzymatic amplification of DNA with a thermostable DNA polymerase. Science 239:487491.

30.Salio, M., V. Cerundolo, and A. Lanzavecchia. 2000. Dendritic cell maturation is induced by mycoplasma infection but not by necrotic cells. Eur. J. Immunol. 30:705-708.

31.Simpson, W.F. and C.S. Stulberg. 1963. Species identification of animal cell strains by immunofluorescence. Nature 189:616-617.

32.Stacey, G.N., B.J. Bolton, and A. Doyle. 1992. DNA fingerprinting transforms the art of cell authentication. Nature 357:261-262.

33.Steube, K.G., D. Grunicke, and H.G. Drexler. 1995. Isoenzyme analysis as a rapid method for the examination of the species identity of cell cultures. In Vitro Cell Dev. Biol. 31:115-119.

34.Stulberg, C.S. 1973. Extrinsic cell contamination of tissue cultures, p. 1-27. In J. Fogh (Ed.), Contamination in Tissue Culture. Academic Press, New York.

Received 31 July 2001; accepted 9 October 2001.

Address correspondence to:

Dr. Barbara Parodi

Interlab Cell Line Collection

National Institute for Cancer Research

L.go R. Benzi, 10

16132 Genoa, Italy

e-mail: iclc@istge.it

For reprints of this or any other article, contact Reprints@BioTechniques.com 